\title{
New Product Technology, Accumulation, and Growth
}

\author{
Faruk A. Khan ${ }^{*}$ \\ Office of the Chief Economist \\ The World Bank
}

\begin{abstract}
This paper asks whether new technological capacity for producing and exporting additional products provides incentives for greater capital accumulation, without being fully reflected in a higher rate of total factor productivity (TFP) growth. Using a highly disaggregated data set of each country's trade flows into the United States (from 1972-94, disaggregated into over 1000 rather than 10s of product categories, and containing over 1 million data points), we construct a direct and independent measure of technological improvements for each country over time based on the number of new product varieties exported to the United States. We show, in a panel data setting, that acquiring the technological capacity for producing new products stimulates more rapid capital accumulation in developing countries, even after holding fixed the rate of TFP growth. Our findings provide evidence against the alternative view that technological improvements are essentially unimportant: a view based on the findings of Young (1995) and others that instances of spectacular economic growth have been associated with unspectacular rates of TFP growth. We provide a model to demonstrate how an expansion in the technological capacity for producing additional products can lead to more rapid factor accumulation, without necessarily improving measured TFP. The findings of this paper suggest that while rapid accumulation of physical and human capital may have characterized the East Asian growth experience, these gains were stimulated by stellar improvements in technological capacity.
\end{abstract}

\section{World Bank Policy Research Working Paper 3846, February 2006}

The Policy Research Working Paper Series disseminates the findings of work in progress to encourage the exchange of ideas about development issues. An objective of the series is to get the findings out quickly, even if the presentations are less than fully polished. The papers carry the names of the authors and should be cited accordingly. The findings, interpretations, and conclusions expressed in this paper are entirely those of the authors. They do not necessarily represent the view of the World Bank, its Executive Directors, or the countries they represent. Policy Research Working Papers are available online at http://econ.worldbank.org.

\footnotetext{
* An earlier version of this paper was circulated under the title "New Product Technology and Factor Accumulation”. I would like to thank Robert Barro, Elhanan Helpman, Marc Melitz, and seminar participants at Harvard University, Williams College, University of California at Santa Cruz, Texas A\&M University, and the WIDER Conference on Globalization for useful comments and suggestions. All errors are my own. Part of the work for this paper was done while I was an Assistant Professor of Economics at Williams College. I would like to thank the economics department at Williams for its support. Questions and comments are welcome at fkhan5@worldbank.org.
} 


\section{Introduction}

Since the late 1990s, India has been in the midst of a rapid accumulation of human capital and skill. In Bangalore, Hyderabad, and elsewhere, large numbers of Aptech and other training centers have been churning out skilled programmers for the country's export-oriented software industry. Often, these individuals are paying many times more for a three month course in programming than they would be paying for a full year in a college degree program. Where did this all start? People close to the software industry will tell you that the arrival of the internet, coupled with the flurry of $\mathrm{Y} 2 \mathrm{~K}$ projects, created an enormous demand for programmers in India. ${ }^{1}$ This has provided a great incentive for individuals to educate themselves in the skills required in the industry.

The point is that human and physical capital are not accumulated in a vacuum. In this paper, we present a novel approach to examine the effect of technological improvements on capital accumulation. In particular, we ask whether new technological capacity for producing and exporting additional products provides incentives for greater capital accumulation, without being fully reflected in a higher rate of total factor productivity (TFP) growth. Using a highly disaggregated data set of trade flows to the United States (by country of origin, from 1972-94, disaggregated into over 1000 rather than 10s of product categories, and containing over 1 million data points), we construct a direct and independent measure of technological improvements for each country over time, based on the number of new product varieties exported to the United States. We show, in a panel data setting, that acquiring the technological capacity for producing new products leads to more rapid accumulation of capital in developing countries, even after holding fixed the rate of TFP growth. ${ }^{2}$

\footnotetext{
${ }^{1}$ These two exogenous events likely had a more pronounced effect in delivering projects to India than to other countries because of a large Indian expatriate presence in the US software industry.

${ }^{2}$ We focus on the accumulation of physical capital. However, preliminary tests indicate that technological improvements also have a positive impact on the incentives to accumulate human capital.
} 
The role of technological progress in the growth process has been a subject of much debate. A good part of this debate is oriented around various interpretations of the growth accounting exercise, which finds that during rapid growth episodes, the measured rates of TFP growth have been quite unspectacular. ${ }^{3}$ In fact, Krugman (1994) has used this finding to suggest that technological improvements were essentially unimportant in generating the high growth episodes in East Asia during the last four decades. We disagree with this interpretation because the simple decomposition of the growth accounting exercise lacks power to make causal interpretations. The findings of the paper suggest that while rapid accumulation of capital may have characterized the East Asian growth experience, these high rates of accumulation were stimulated by stellar improvements in technological capacity. Moreover, the improvements in technological capacity were not fully reflected in higher rates of TFP growth.

There are a myriad of reasons why technological improvements may not be reflected in measured TFP growth rates. ${ }^{4}$ As is well known, calculations of TFP growth are highly sensitive to the choice of the capital share in income. Even if the capital share can be estimated from the data, in most cases, data limitations allow this to be estimated at only one point in time. This one point estimate of the capital share is then used to compute TFP growth rates for the country at different points in time. However, if the production function has a less than unitary elasticity of substitution, then clearly capital deepening will cause the capital share of income to fall over time, so that the calculated TFP growth rates will be biased downward. Furthermore, as Rodrik (1997) shows, even if the data allow a distinct capital share to be computed for each time period, with a less than unitary elasticity of substitution and substantial labor augmenting technological progress, the calculated TFP growth rates will fail to reflect the substantial technological improvements.

The model presented in this paper provides another reason for why measured TFP growth rates may not accurately reflect improvements in technological capacity. Our

\footnotetext{
${ }^{3}$ See Young (1995).

${ }^{4}$ See, for example, Rodrik (1997), Hsieh (1999), and Young (1998).
} 
model merges a Dornbusch, Fischer, Samuelson (1977) model of international trade and product specialization with an $A K$ version of the Ramsey model of accumulation. An increase in the range of products over which a country has expertise initially raises TFP and stimulates greater accumulation. However, greater accumulation in turn induces a decline in TFP back to its initial level as the country experiences a deterioration in its terms of trade. ${ }^{5}$ Thus, our model clarifies how acquiring the technological capacity for producing and exporting additional products can lead to a higher rate of capital accumulation, but not be reflected in a higher measured rate of TFP growth in the long run.

Conceptually, if output and inputs are measured perfectly in constant prices, we will not necessarily want our measures of TFP growth to be affected by changes in terms of trade. However, in practice, there are a number of reasons why terms of trade changes can affect measured TFP growth rates. In very simple terms, whenever the constant price base year is updated in national accounts, the relative weights placed on different products change. If a country experiences a terms of trade deterioration in products experiencing rapid productivity growth, measured TF P growth rates will be biased downward. ${ }^{6}$

Given the myriad of problems associated with measured rates of TFP growth, it becomes necessary to have an independent measure of technological improvements, to assess its effect on capital accumulation and to determine whether it is fully reflected in measured TFP growth rates. One of the innovations of this paper is that we construct a direct and independent measure of technological improvements. Using a rich data set of trade flows into the United States, we directly measure the evolution of each country's capacity to produce additional products for the world market over time. This measure of new product technology has the added advantage of being

\footnotetext{
${ }^{5}$ Other work examining the process of capital accumulation within countries engaged in international trade includes Stiglitz (1970), Ventura (1997), and Acemoglu and Ventura (2002).

${ }^{6}$ There is a substantial literature on terms of trade bias in TFP measurement. See Diewert and Morrison (1986) and Kohli (2003).
} 
independent of national income accounts data, and thus does not suffer from the problems which plague TFP measurements.

Empirically, the main difficulty in testing for the effect of new product technology on capital accumulation is the problem of reverse causality: a higher growth rate of capital can itself allow countries to produce and export a greater range of products over time. We adopt a number of empirical strategies for dealing with this problem. Most importantly, we exploit the panel structure of our data set to show that a larger increment of new product technology in period $t-1$ leads to a higher rate of capital accumulation in period $t$, even after we hold fixed the rate of accumulation in period $t-1$. This provides compelling evidence of an effect of new product technology on the rate of capital accumulation because we are able to hold fixed exogenous factors responsible for different rates of capital accumulation. We also show empirically that there exists a positive effect of new product technology on capital accumulation even after we hold fixed the rate of $T F P$ growth. Thus, the contribution of technological improvements in the form of new product technology is not fully reflected in the measured rate of TFP growth. This suggests that using the TFP growth rate to assess the contribution of technological improvements-as is done in certain interpretations of the growth accounting exercise of Young (1995) and others-is likely to lead to an underestimation of the importance of technological improvements.

The primary policy implication arising from this paper is that developing countries attempting to raise their investment (and enrollment) rates must pay close attention to building their technological capacity: in particular, to expanding the range of products they are able to competitively export to the world market. We do not deny that fiscal measures, financial deepening, tax incentives, and other policy measures can mobilize greater resources and raise rates of capital accumulation. However, focusing on such measures alone amounts to focusing on only one side of the equation: unless developing countries acquire the capacity to productively utilize the greater resources, these resources may not materialize in the first place. On the other hand, 
acquiring the expertise to competitively produce and export a wider range of products is likely to provide powerful incentives to accumulate greater resources.

A detailed look at which policy measures are most effective in enabling countries to acquire the technological capacity for producing additional products is an interesting area for further work. In this paper, we focus on marshalling evidence to demonstrate the effects of such technological improvements on capital accumulation. However, our measure of technological improvements based on new product varieties opens up a potentially lucrative research agenda which would seek to explain why certain countries have been more successful in expanding the range of products over which they have expertise.

There exists a previous literature on the determinants of savings which addresses the question of why rates of capital accumulation differ across countries and over time. While this literature does not focus explicitly on the role of technological improvements, one of the salient findings is that high savings rates are associated with high growth rates. ${ }^{7}$ Indeed, Carroll and Weil (1994) find that growth causes savings, but that savings does not cause growth. This is a strong suggestion that technological improvements provide incentives for higher rates of savings and capital accumulation. Along a somewhat different line, Foster and Rosenzweig (1996) show that exogenous technological improvements in the form of high yielding seed varieties during the Green Revolution in India led to higher rates of human capital accumulation in areas where adoption was the greatest.

In order to satisfactorily answer the question posed in this paper, we need to address three fundamental issues. First, we need to make the case that our constructed measure of new product technology is a reasonable measure of technological improvements. Second, we need to provide a theoretical model to understand why such technological improvements should lead to a higher rate of capital accumulation without

\footnotetext{
${ }^{7}$ See Schmidt-Hebbel and Serven (1996) and Loayza, Schmidt-Hebbel, and Serven (2000).
} 
being fully reflected in a higher measured rate of TFP growth. And third, we need to empirically demonstrate that our measure of new product technology does indeed lead to a higher rate of capital accumulation without being fully reflected in a higher measured rate of TFP growth. The following three sections address each of these issues in turn.

\section{Measure of Technological Improvements}

The concept of technological improvements we use throughout this paper is the capacity to competitively produce additional products for the world market. Thus, technology is specific to product lines and essentially reflects knowledge and expertise to competitively organize production of a particular product and deliver it to buyers on the world market. This is similar to the concept of technology in the technology, trade, and new growth literature, pioneered by Grossman and Helpman (1991) and Romer (1990). The one distinction is that in this paper, technology is explicitly the variety of products a country is able to produce, rather than the variety of intermediate inputs the country is able to utilize in production or the variety of products the country is able to consume, both of which are affected by the total variety of products available in the world to freely trading nations. The model presented in our paper makes clear why the number of products a country is able to produce is the appropriate measure of technology for our purposes.

We measure expansion in the number of products each country is able to produce using data on trade flows into the United States by country of origin. This data, compiled by Feenstra (1996), is disaggregated into over 1000 product categories (at the 5-digit SITC level) and covers 160 countries or territories of origin, from 1972-94. ${ }^{8}$ We focus on the 87 countries for which we have capital stock data. For each countryyear combination, we count the number of first-time zero to positive conversions

\footnotetext{
${ }^{8}$ The original form of the data contains a larger number of product categories. However, since we are tracking products over time, in order to avoid problems associated with SITC reclassifications in 1978 and 1989, we use only those categories which exist in the data in all years. This leaves us with slightly over 1000 product categories.
} 
within product lines. We require each within-category export initiation to be above $\$ 10,000$ and we require the initiation to be followed up with one immediate subsequent year of exports: these requirements are intended to rule out erratic exports and to ensure that the export initiations are substantial enough to signal that the country has acquired technological expertise in the product concerned. Then, the number of such export initiations for each country-year reflects the number of new products the country has learned to produce competitively for the world market during that year. Thus, our NewProducts variable is defined as follows:

$$
\text { NewProduct } s_{i t}=\sum_{j=1}^{N} I_{i j t}
$$

where $I_{i j t}=1$ if year $t$ is the first year in which country $i$ exports product $j$, and $I_{i j t}=0$ otherwise..$^{9,10}$

Table A1 provides a snapshot of the raw data. It lists 3 products exported by Thailand, starting from the first year of exports. This snapshot provides a sense of the high level of disaggregation in the data. In addition, it is interesting to note that the product export initiations occur post-1972, and in these three cases, long after 1972. This feature of the data-the fact that there are many product export initiations by countries all along the time period-is a result of the high level of disaggregation. If we were instead using data at the 2-digit level, most "products" would be exported by all countries in all years, and tracking products over time would not be a meaningful exercise.

There are a number of additional issues in measuring new product technology using data on export initiations to the United States. First, we are measuring the number of

\footnotetext{
${ }^{9}$ To be more accurate, $I_{i j t}=1$ if year $t$ is the first year in which country $i$ exports more than $\$ 10,000$ worth of product $j A N D$ country $i$ also exports more than $\$ 10,000$ worth of product $j$ in year $t+1$.

${ }^{10}$ It is interesting to note that Feenstra and Rose (2000) use disaggregated data on imports into the United States to rank products by level of technological sophistication: a more sophisticated product is one which is, on average, imported into the United States in a later year. In our analysis, we treat all products identically: first time exports of any product by a country amounts to an identical increment of technological capacity.
} 
new products in exports rather than in domestic output. This is appropriate because the concept of technology we are interested in is the capacity to become a competitive producer of the product for the world market. If a product in domestic output is produced under trade protection and is of shoddy quality, it does not signal that the country has acquired expertise in that product. For many developing countries with limited domestic market size, it is important to be able to produce the product competitively for the world market, and non-zero exports of the product to the United States serves as a better signal, albeit a noisy signal, that they have acquired the capacity to do so.

Second, we are using data on exports to the United States, rather than to all destinations. While this choice is dictated by the much higher level of disaggregation of the data on trade flows into the United States, there are good reasons why this may not be a serious limitation. First, the United States is the single largest market and expertise to competitively export a new product is likely to show up in exports to the United States. In fact, the ability to export to the US market provides us with a uniform standard against which we assess product expertise. Second, since we are not measuring the quantity of exports, but rather the $0 / 1$ signal of export initiations within product categories, our consideration of only the US market is less likely to be problem.

Of course, distance from the United States is likely to affect the incremental number of products a country exports to the US over time. In addition, larger countries are likely to have a more diversified production base, and this can show up in a larger incremental number of products exported to the US as transport costs fall over time. We thus construct an alternative measure of technological improvements, NewTech, by filtering out the effect of country size and distance as follows:

$$
\ln \left(\text { NewProducts }_{i t}=\theta_{1} \ln (\text { population })_{i t}+\theta_{2} \ln \left(\text { distance }_{i}+\varepsilon_{N E W T E C H, i t}\right.\right.
$$

Distance and country size explain about $15 \%$ of the variation in NewProducts in the pure cross-section and about $10 \%$ in the panel. We utilize both measures, 
NewProducts and NewTech, in our empirical work. Table A2 lists the top ten and bottom five countries for each of our two measures of expansion in technological capacity for the 1972-94 period. South Korea, for example, exported 180 product categories in 1972 and during the 1973-94 period, it acquired the capacity to export 589 additional products. On the other hand, Ethiopia exported 14 products in 1972 and acquired the capacity to export 17 additional products between 1973-94. After adjusting for distance and country size, India and Mexico drop out of list of ten countries which have most rapidly expanded their technological capacity. It is reassuring to note that four of the six developing countries in the list of top ten NewTech countries are Taiwan, Malaysia, South Korea, and Singapore. While this table lists the number of new products over the entire 1973-94 period for each country, our empirical work using panel data divides up the time period into 5-year intervals and uses the number of new products initiated by countries during each interval.

Of course, as pointed out earlier, it is natural to suspect that our NewProducts and NewTech measures not only provide a signal of new technological capacity, but are also influenced by exogenous capital accumulation and by omitted third variables that are correlated with exogenous capital accumulation. We would like to call attention to two points in this regard. First, since we count the $0 / 1$ signal of whether or not a product is exported, our measure of expansion in technological capacity is likely to be more exogenous than if we had measured the quantity of exports. Second, when we test for the effect of NewProducts and NewTech on capital accumulation, we will exploit the panel structure of our data to hold fixed exogenous factors responsible for different rates of capital accumulation.

In order to throw further light on whether it is new technological capacity or merely capital deepening that is picked up by our measure of NewProducts, it is interesting to consider some recent informal evidence presented by Hausmann and Rodrik (2002). The authors take pairs of countries with similar factor endowments-Bangladesh and Pakistan, Honduras and the Dominican Republic, and Taiwan and South Korea-and 
investigate whether the countries within each pair have similar patterns of specialization, as one would expect. For this purpose, they look at each country's disaggregated exports to the United States.

The authors find that while similar factor endowments might lead to a similar pattern of specialization at a fairly aggregate 2-digit level, it does very little to explain which products countries export at a more disaggregated 6-digit level. For example, out of the top 25 6-digit products in Pakistan's export basket to the United States, there are many products for which Bangladesh's exports are very small or zero. A similar pattern appears when one looks at Pakistan's exports of the top 25 products in Bangladesh's export basket to the United States. ${ }^{11}$ Thus, as Hausmann and Rodrik point out, while factor endowments might help us determine that Pakistan or Bangladesh will export labor-intensive manufactures, that still leaves hundreds of products up for grabs. It seems reasonable to think, therefore, that acquired technological capacity must have something to do determining with which of these disaggregated products and how many of these products each country will produce over time.

\section{Model and Empirical Implications}

The model presented here makes explicit how acquiring the technological capacity for producing and exporting new products can lead to a higher rate of capital accumulation, without being reflected in a higher measured rate of $T F P$ growth in the long run. We merge a Dornbusch, Fischer, Samuelson (1977) model of international trade, productivity differences, and specialization with an $A K$ version of the Ramsey model of accumulation. A technological improvement allows a country to produce and export an additional range of products. This initially raises $T F P$ and stimulates faster accumulation. However, greater accumulation in turn induces a decline in TFP back

\footnotetext{
${ }^{11}$ It should be pointed out that for both countries, the top 25 6-digit products account for more than 60 percent of exports to the United States.
} 
to its initial level as the country experiences a deterioration in its terms of trade. ${ }^{12}$

In order to understand why more rapid accumulation induces a decline in TFPthrough terms of trade-in the long run, notice that specialization is a fundamental element of our model. The domestic economy specializes in a certain subset of products, although this pattern of specialization is endogenously determined in equilibrium. Then, as a country accumulates capital more rapidly, it increases production of the commodities in which it specializes, and thereby experiences a decline in its terms of trade. While it also expands the range of products it produces and exports, this is not sufficient to prevent a terms of trade deterioration.

Our model shares some common features with another model developed separately by Acemoglu and Ventura (2002). Both models combine international trade and specialization with $A K$ production and accumulation within countries. In both models, although production is $A K$, the market in effect imposes diminishing returns. If a country accumulates capital faster than the rest of the world, it experiences a terms of trade decline, which reduces the returns to capital and discourages further accumulation. However, there are some crucial differences between the models. Acemoglu and Ventura (2002) adopt a fixed pattern of specialization using the Armington assumption that products are differentiated by country of origin. In our model, the pattern of specialization is determined endogenously in equilibrium from differences in relative productivities. Acemoglu and Ventura also assume that the cross country distribution of technology is time-invariant and their focus is on explaining how a stable world income distribution is achieved. On the other hand, our focus is on examining how technological improvements in within a country affects capital accumulation and measured TFP growth in that country over time.

\footnotetext{
${ }^{12}$ As pointed out earlier, conceptually, it may not necessarily be desirable to have terms of trade changes affect measures of TFP growth. However, there is a substantial literature explaining why, in practice, terms of trade changes can indeed affect measured TFP growth rates. Thus, when we refer to measured TFP growth rates, we will be referring to estimates of TFP growth that are influenced by changes in terms of trade.
} 


\subsection{A Simple Model}

The product space takes the form of a continuum of products spread over the unit interval $[0,1]$. There is no innovation: just a fixed product space. There is only one factor of production, $K$-construed as a broad measure of capital or of the resources of production. For simplicity, we restrict ourselves to the two-country setting, with a domestic economy and the rest of the world. While the product space is fixed, technological improvements in the domestic economy can allow it to produce and export a wider range of products. There is no capital mobility across countries.

Consumption. The $K$ stock is owned by consumers in each country and $K$ can be accumulated through savings. A representative consumer optimizes intertemporally in each country to decide how much to consume and how much to save:

$$
U_{t}=\int_{t}^{\infty} e^{-\rho(\tau-t)} \log \left(C_{\tau}\right) d \tau
$$

where $C_{\tau}$ is a consumption index which depends on the consumption of every product variety $z \in[0,1]$ in the unit interval through the following instantaneous utility function:

$$
\log C=\int_{0}^{1} \log c(z) d z .
$$

Note that this instantaneous utility function is of the Cobb-Douglas form, and implies that each atomistic product $z$ will receive an equal weight in expenditure. Let $p(z)$ denote the price of each product. Then, the consumer's expenditure minimization problem can be solved to show that the price of the consumption index is given by the following: $P=\exp \left\{\int_{0}^{1} \log p(z) d z\right\}$. The homothetic structure of instantaneous preferences implies that expenditure will be spread evenly over the unit interval, so that spending on any interval $\left(z_{1}, z_{2}\right)$ is given by $\int_{z_{1}}^{z_{2}} p(z) c(z) d z=\left(z_{2}-z_{1}\right) P C$.

Production. Both countries are physically able to produce the entire range of products over the unit interval. However, they are able to do so with different technology parameters. In particular, the unit capital requirement for producing product $z$ is 
$a(z)$ in the domestic country and $a^{*}(z)$ in the foreign country. Products are ordered over the $[0,1]$ interval such that relative productivity of the domestic country is falling with $z$, as follows:

$$
A(z) \equiv \frac{a^{*}(z)}{a(z)}, \quad A^{\prime}(z)<0
$$

Capital resources earn a return of $w_{K}$ in the domestic economy and $w_{K}^{*}$ in the foreign economy. The size of capital resources in the domestic and foreign economy are given by $K$ and $K^{*}$ respectively. We normalize the price of the $z=1$ product to unity: $p(1)=1$.

Equilibrium without accumulation. Let us first ignore the issue of accumulation and solve for the simple Dornbusch-Fischer-Samuelson equilibrium with exogenously given factors of production in the two countries. Note that all products for which $a(z) w_{K}<a^{*}(z) w_{K}^{*}$ will be produced exclusively in the domestic country, whereas the rest will be produced exclusively in the foreign country. The equilibrium relative returns will be given by the following:

$$
\omega_{K} \equiv \frac{w_{K}}{w_{K}^{*}}=\frac{a^{*}(\widetilde{z})}{a(\widetilde{z})}
$$

where $\widetilde{z}$ is the cutoff product, so that all products in the range $(0, \widetilde{z})$ are produced in the domestic country and the rest are produced abroad. Given this specialization pattern, our specification of preferences yielding a uniform distribution of expenditure over the unit interval, implies that a share $\widetilde{z}$ of world expenditure will be spent on domestic products. If so, we have that $\widetilde{z}\left(w_{K}^{*} K^{*}+w_{K} K\right)=w_{K} K$. This gives us the following:

$$
\frac{w_{K}}{w_{K}^{*}}=\frac{\widetilde{z}}{1-\widetilde{z}}\left(\frac{K^{*}}{K}\right)
$$

Equations (4) and (5) together determine the pattern of specialization and the relative returns of the domestic economy, $\left(\widetilde{z}, \omega_{K}\right)$, as a function of the technology parameters and factor endowments. Note that because of our particular normalization of prices, $p(1)=1$, we have that ${ }^{13}$ :

$$
w_{K}^{*}=\frac{1}{a^{*}(1)} \quad, \quad w_{K}=\omega_{K} \frac{1}{a^{*}(1)}
$$

\footnotetext{
${ }^{13}$ The purpose of this model is to explain domestic variables relative to those of a rest of the
} 
Accumulation. Now, we introduce accumulation and intertemporal optimization by households. Households in the domestic economy hold capital resources $K$. They rent out their capital to firms and obtain a return $w_{K} K$. They consume part of this income and save the rest to add to their resource holdings. So, we have the following relation for use of final output:

$$
w_{K} K=P C+P \dot{K} \quad \text { or } \quad \frac{w_{K} K}{P}=C+\dot{K}
$$

and similarly for the use of final output in the foreign country:

$$
\frac{w_{K}^{*} K^{*}}{P}=C^{*}+\dot{K}^{*}
$$

Note that we ignore depreciation for simplicity.

Next, intertemporal optimization by households implies that consumption must evolve according to the following in the foreign and domestic economies respectively:

$$
\begin{gathered}
\frac{\dot{C}^{*}}{C^{*}}=\frac{w_{K}^{*}}{P}-\rho=\frac{1}{a^{*}(1) P}-\rho \\
\dot{C}=\frac{w_{K}}{P}-\rho=\frac{\omega_{K}\left(\frac{a^{*}(\tilde{z})}{a(\tilde{z})}, \frac{K^{*}}{K}\right)}{a^{*}(1) P}-\rho
\end{gathered}
$$

where $\omega_{K}\left(\frac{a^{*}(\tilde{z})}{a(\tilde{z})}, \frac{K^{*}}{K}\right)$ indicates that the relative return to capital is a function of the technology parameters (at the cutoff product) and the relative size of capital resources.

Steady-State Solution. We solve for a steady-state equilibrium with a constant share of products $\widetilde{z}$ in the domestic economy. The intuition behind the steady-state solution is clear. Once we allow accumulation, the capital stocks in the two countries world benchmark: in particular, to explain the effect of a technological improvement in the domestic economy relative to the rest of the world. Thus, if we think of the $a^{*}(z)$ parameters as being fixedand instead focus on changes in the $a(z)$ parameters-then our normalization of prices also fixes foreign wages as well as all prices for goods produced in the rest of the world. 
respond to the different rates of return. In steady-state, with a constant specialization pattern $(\widetilde{z})$, the relative size of the capital stock in the two countries $\left(\frac{K^{*}}{K}\right)$ must be fixed. ${ }^{14}$ Thus, we have that:

$$
\hat{K}=\hat{K}^{*}
$$

Furthermore, in each of the two countries in steady-state, the rate of growth of the capital stock must equal the growth rate of consumption: ${ }^{15}$

$$
\hat{K}=\hat{C} \quad \text { and } \quad \hat{K}^{*}=\hat{C}^{*}
$$

So, from equations (11) and (12), we see that consumption must grow at the same rate in the two countries. If so, since the two countries have the same subjective discount rate, equations (9) and (10) tell us that the rates of return must be equalized in the two countries, so that we have:

$$
\omega_{K}\left(\frac{a^{*}(\widetilde{z})}{a(\widetilde{z})}, \frac{K^{*}}{K}\right)=1
$$

Thus, the endogenous accumulation of capital equalizes the returns to capital in the two countries in steady-state. Furthermore, (13) immediately implies that

$$
a(\tilde{z})=a^{*}(\tilde{z})
$$

In other words, in steady-state, each country produces only those goods in which it has an absolute advantage. ${ }^{16}$ Figure 1 depicts the basic steady-state solution in product space. The exogenously given technology parameters $a(\tilde{z})$ and $a^{*}(\tilde{z})$ pin

\footnotetext{
${ }^{14}$ Note that if $\widetilde{z}$ is constant, then (4) tells us that $\omega_{K}$ will also be constant in steady-state. Then, from (5), we have that $\frac{K^{*}}{K}$ will be fixed in steady-state.

${ }^{15}$ We can show that if $\widetilde{z}$ and $\omega_{K}$ are constant, then $P$ is also constant in steady-state. This requires us to assume that the technology parameters $a(z)$ and $a^{*}(z)$ are either constant or falling uniformly over time at the same rate in both countries. If so, then

$$
\log P=\tilde{z} \log \omega_{K}+\int_{0}^{\tilde{z}} \log \frac{a(z)}{a^{*}(1)} d z+\int_{\tilde{z}}^{1} \log \frac{a^{*}(z)}{a^{*}(1)} d z
$$

is constant provided that $\tilde{z}$ and $\omega_{K}$ are constant. It follows that $\frac{\omega_{K}}{P}$ is constant. Then, equations (7) and (8) tell us that with a constant steady-state growth rate of capital in each country, we get equation (12).

${ }^{16}$ Note that the existence of such a steady-state equilibrium requires us to assume that each country has an absolute advantage in some range of goods.
} 
down the technology schedule $A(z)$, and steady-state equilibrium is always reached at the point where this schedule evaluates to 1 . The domestic economy produces and exports products in the range $(0, \widetilde{z})$-i.e. those products in which its technological expertise is at least as good as the rest of the world: $a(\tilde{z}) \leq a^{*}(\tilde{z})$. Finally, (13) and (5) give us that:

$$
\frac{K}{K+K^{*}}=\tilde{z}
$$

We thus obtain the clear and simple result that the endogenously determined relative size of the capital stock in the domestic economy is exactly given by the share of products in which it has technological expertise.

The intuition for these results is clear. If the domestic economy produces the range of commodities for which $a(z) w_{K}<a^{*}(z) w_{K}^{*}$, and the rates of return to capital are equalized in steady state, then the domestic economy must produce the range of commodities for which $a(z)<a^{*}(z)$ in the steady state equilibrium. Second, since consumers spread their expenditure evenly over the unit interval, the share of commodities produced in the domestic economy $(\widetilde{z})$ must equal the domestic economy's share of world income. However, if returns to capital are equalized in the steady state, then the share of commodities produced in the domestic economy $(\widetilde{z})$ will equal the domestic economy's share of the world capital stock. At the root of both steady state results is the fact that returns to capital are equalized in steady state. And the intuition for that is clear: if the returns to capital in the domestic economy is higher, that induces faster capital accumulation, which in turn induces a terms of trade decline and therefore, also a decline in the returns to capital in the domestic economy.

\subsection{Empirical Implications of a Technological Improvement.}

Suppose that, starting from steady-state, the domestic economy experiences a technological improvement which allows it to produce an additional increment $\Delta z_{1}$ of products. Specifically, this is represented by the domestic economy's $a(z)$ parameter falling below $a^{*}(z)$ for some range of products. Figure 2 depicts such a technological improvement. Point A denotes the initial steady-state equilibrium. The technological 
improvement has the following effects:

- There is an immediate jump in the relative returns to capital in the domestic economy. The equilibrium moves immediately from point A to point B.

- Beginning immediately and over time, the higher relative returns to capital causes the rate of capital accumulation in the domestic economy to exceed that of the rest of the world. As a result of this higher rate of accumulation, the equilibrium moves over time from point B toward the new steady-state equilibrium at point $\mathrm{C}$.

- We get an immediate expansion in the number of products the domestic country exports. Over time, we get a further expansion in the number of products exported by the domestic economy. What is happening here? While the country's $a(z)$ parameter fell below $a^{*}(z)$ for the entire range $\left(\widetilde{z}, \widetilde{z}^{\prime}\right)$, it does not export all these additional products immediately because the cost of capital in the domestic economy $\left(w_{K}\right)$ rises above that of the rest of the world. As the relative returns (costs) revert to unity, the country eventually exports all the additional products in which it has acquired expertise.

One of the empirical implications arising from the model is that if a country has technological expertise in exporting a higher number of products, relative to its capital stock, then it should experience a larger growth rate of its capital stock. Recall that according to equation (15), the relative size of the domestic economy's capital stock in steady-state is given by the range of products $(z)$ that it is able to competitively export. This implies that, if the number of products a country is able to export, relative to its capital stock, $\left(\frac{z}{K}\right)$, is higher than that of the rest of the world, then the country's capital stock should be growing faster than the rest of the world.

A second empirical implication clear from our discussion above is that, starting from steady-state or from any other equilibrium point, a technological improvement-in the 
form of an expansion in the number of products a country is able to export-raises the returns to capital and leads to a faster rate of growth of the capital stock. In fact, the greater is the increment in new products, the higher is the rate of capital stock growth.

Finally, measured aggregate productivity or TFP is given by $\frac{p(z) Q(z)}{K(z)}=w_{K}$. Productivity growth is given by $\hat{Y}-\hat{K}=\hat{w}_{K} \cdot{ }^{17}$ So, while a technological improvement leads to an initial upward jump in the productivity level, over time, as the capital stock responds along the adjustment path, $\omega_{K}$ reverts to unity. Indeed, in the new steadystate, the country has a higher relative $K$ stock, but its $T F P$ level is unchanged from before the technological improvement. In other words, if we compare a country which has experienced a technological improvement to one which has not, then the former will record a higher rate of capital accumulation, but no difference in its rate of $T F P$ growth.

\section{Empirical Strategy and Results}

In line with the empirical implications emerging from our model, we would like to test for the effect of our measures of technological improvements (NewProducts \& NewTech) on the rate of capital accumulation. Furthermore, we would like to test whether this effect of new product technology on capital accumulation remains even after we hold fixed the rate of $T F P$ growth.

\subsection{The Effect of NewProducts}

There are two significant difficulties in implementing the estimation. First, there is the reverse causality problem: namely, that the rate of capital accumulation itself can influence the number of new products a country exports over time. Thus, if there are reasons other than technological improvements why some countries accumulate

\footnotetext{
${ }^{17}$ As pointed out earlier, the measure of $T F P$ we look at is one which would be affected by changes in terms of trade, because in practice, measured $T F P$ growth rates are likely affected by terms of trade changes.
} 
more capital than others-and we agree that there are-then, countries with higher rates of capital growth will produce more new products simply because there are more resources available. Recall, however, that we count the 0/1 signal of whether or not a product is exported, rather than the size of exports itself. Thus, our measure of expansion in technological capacity is likely to be more exogenous than if we had measured the quantity of exports. Still, we acknowledge that there can be a reverse causality problem. Second, there is the problem of spurious correlation: omitted third variables, which generally increase the efficiency of production, can positively impact both the rate of capital accumulation as well as the number of new products a country exports.

We employ a number of complementary econometric specifications to deal with the problems of estimation. In our first specification, we control for a society's inherent tendency to accumulate capital using age dependency ratios (i.e. the percentages of the population over 65 years of age and under 15 years of age). ${ }^{18}$ Furthermore, we control for omitted third variables that affect the efficiency of production using the initial level of TFP, as well as the TFP growth rate. We have previously made the argument that TFP measures are biased by terms of trade changes. In our model, it is terms of trade augmented TFP $\left(\frac{p(z) Q(z)}{K(z)}=w_{K}\right.$ in our model) that affects the rate of capital accumulation. Of course, our model does not allow us to think about third omitted variables that can independently affect both capital accumulation and NewProducts. Ultimately, our purpose in controlling for TFP and TFP growth is to not only generally control for omitted third variables, but also to determine whether the effect of NewProducts on capital accumulation holds even after we hold fixed the rate of TFP growth.

\footnotetext{
${ }^{18}$ These demographic variables have been found to explain a significant part of the cross-country variation in savings and investment rates. See Schmidt-Hebbel and Serven (1996) and Loayza, Schmidt-Hebbel, and Serven (2000).
} 
The econometric specification takes the following form:

$$
\begin{aligned}
K G r_{i t}= & \alpha_{0}+\alpha_{1} \ln (K / L)_{0, i t}+\alpha_{2} \ln (\text { NewProducts })_{i t}+\alpha_{3} \ln (T F P)_{0, i t} \\
& +\alpha_{4} \ln (\text { TFPGr })_{i t}+\alpha_{5}(\text { OldDep })_{i t}+\alpha_{6}(\text { YoungDep })_{i t}+\xi_{t}+\varepsilon_{i t}
\end{aligned}
$$

It is worthwhile to point out that the variable NewProducts, rather than the growth rate of new products, is the appropriate measure of technological improvements here. This is because the product space is fixed in both the theory (by the unit interval) and in the data. As figure 2 shows, starting from steady-state, a greater increment in the share of the fixed product space that a country is able to produce (i.e. a greater $\Delta z$ or NewProducts) will lead to a greater effect on the growth rate of capital along the adjustment path.

Our data on capital stock comes from Nehru and Dhareshwar (1994), as updated by Bosworth and Collins (1996). The level and growth rate of TFP have been calculated using both physical and human capital and using a physical capital share of 0.4. ${ }^{19}$ The Old and Young age ratios are from the World Bank. We divide the 1972-94 period into four 5-year periods and one 3 -year period (1972-75). ${ }^{20}$ The estimation is carried out using time period fixed effects and using a heteroskedasticity-consistent estimation procedure.

Table 2 presents the results of estimating a number of variants of (16). In the specification including all variables except for the TFPGr rate (column 3), the estimated coefficient on $\ln$ (NewProducts) is 0.0040 and is statistically significant at the $5 \%$ level. Thus, even after controlling for differences in a country's inherent tendency to save, as well as differences in the initial level of $T F P$, a greater expansion in the number of NewProducts learned is associated with more rapid rates of capital accumulation. It is interesting to note that the magnitude of the effect is larger for the

\footnotetext{
${ }^{19}$ Our measure of TFP is $\frac{Y}{K^{\alpha}(H L)^{1-\alpha}}, \alpha=0.4$. Human capital data is from Bosworth and Collins (1996), which itself is based on Barro and Lee (1993).

${ }^{20}$ The results are essentially unchanged if we exclude the initial 3-year period. Of course, $K G r_{i t}$ and NewProducts $i$ are each annual averages over the time period concerned.
} 
subset of non-OECD developing countries (column 4). ${ }^{21}$ This is not difficult to understand. In developing countries, technological improvements are more likely to take the form of acquiring the expertise to produce a greater share of the fixed product space. The OECD countries likely already possess the ability to produce products in most of the product categories in our data. In these countries, technological improvements are more likely to take the form of either increased product quality or greater variety within certain product categories.

Comparing columns $3 \& 4$ with columns $5 \& 6$, we see that including the TFPGr rate in the specification reduces the magnitude of the estimated coefficient on $\ln$ (NewProducts), although the coefficient remains statistically significant at the $5 \%$ level. The reduced magnitude can be due to a number of reasons. First, as is our intention, the TF PGr rate may be controlling for improvements in omitted third variables (e.g. a reduction in political instability) which positively affect both NewProducts and the growth rate of capital. This is akin to the reason why including the initial level of TFP reduces the magnitude of the coefficient on $\ln$ (NewProducts). Second, there is the possibility that a technological improvement in the form of acquiring the capacity to produce new products can itself be reflected in a higher rate of TFPGr during the 5-year period. This is not contrary to the predictions of the theory. Recall that according to the theory, TFP is unaffected by technological improvements only in the long run, once the capital stock has responded fully to the improvement. Along the adjustment path, NewProducts can positively impact TFP (and hence the measured TFPGr rate over the 5-year period). On the other hand, the empirical finding in columns $5 \&$ 6 that the effect of NewProducts on the growth rate of capital remains statistically significant even after holding fixed the TF PGr rate, suggests that the measured TFP growth rates do not fully capture improvements in technological capacity. In other words, the results indicate that new product technology does lead to a higher rate of capital accumulation, without being fully reflected in a higher measured rate of TFP

\footnotetext{
${ }^{21}$ For the OECD countries, the estimated coefficient is actually negative and significant, although the statistical significance of the negative coefficient disappears when subjected to robustness checks.
} 
growth.

Finally, examining the effect of including the Old and Young age ratios in the estimation (compare columns 1 and 2) serves as an indirect test of reverse causality. It is reasonable to expect that the age ratios have an effect on the growth rate of capital, but no independent effect on NewProducts. Indeed, as we expected, the magnitude of the estimated coefficient on $\ln$ (NewProducts) declines from 0.0084 to 0.0057 (for the full sample of countries), suggesting that reverse causality is a problem. While the estimated coefficient remains statistically significant even after we use the Old and Young age ratios to control for exogenous reasons why savings rates differ across countries, there is still the nagging concern that we have not controlled for all exogenous reasons for why some countries save more than others. Thus, a plausible argument can be made that our results from the estimations in Table 2 do not conclusively demonstrate causality. We thus turn to our second set of specifications, where we look at the effect of the initial number of Products on the growth rate of capital.

\subsection{The Effect of the Initial Number of Products}

According to the theory, a higher initial number of products, relative to the initial level of the capital stock, leads to a faster growth rate of capital. Since the relative size of an economy's $K$ stock in steady state is fully determined by the number of Products (z) in which it has technological expertise (see equation 15), a lower level of the $K$ stock relative to the number of Products implies that the country is farther behind its steady-state level of $K$, and hence that it must experience a higher rate of capital accumulation. In fact, the theory predicts that conditional on the initial level of capital, both Product $s_{0, i t}$ as well as NewProducts $s_{i t}$ should have an effect on the growth rate of capital: the former because it determines the current steady-state level of capital and the latter because it pushes the steady-state level of capital farther ahead of the current level of $K$. 
Before we test for the effect of both variables jointly, we test separately for the effect of the initial number of products. The specification takes the following form:

$$
\begin{aligned}
K G r_{i t}= & \alpha_{0}+\alpha_{1} \ln (K / L)_{0, i t}+\alpha_{2} \ln (\text { Products })_{0, i t}+\alpha_{3} \ln (\text { TFP })_{0, i t} \\
& +\alpha_{4} \ln (\text { TFPGr })_{i t}+\alpha_{5}(\text { OldDep })_{i t}+\alpha_{6}(\text { YoungDep })_{i t}+\xi_{t}+\varepsilon_{i t}
\end{aligned}
$$

Recall that Products $_{0, i t}$ here is the cumulative number of products that each country has ever exported up to the beginning of each 5-year period. We use the cumulative number of products, rather than the actual number of products exported in the particular year corresponding to the beginning of each 5-year period, because we seek to measure the range of products in which the country has knowledge or technological expertise. Thus, the underlying notion is that product-specific knowledge or expertise, once acquired, is not lost.

The results of the estimation are presented in table 3. The estimated coefficient on the initial number of Products is positive and statistically significant at the $5 \%$ level in all variants of specification (17), for the sample of non-OECD developing countries. Since the initial number of products precedes the growth rate of capital over the 5year period, there is a good case to be made for a causal interpretation of this finding. Thus, developing countries starting out with expertise in producing a larger number of Products relative to their initial stock of capital will experience a faster rate of capital accumulation.

In the specification including the initial level of $T F P$ (in addition to the initial number of Products), the magnitude of the estimated coefficient on Products $_{0, i t}$ is much reduced (columns 4 and 5). Indeed, for the full sample of countries, the estimated coefficient on Products $s_{0, i t}$ is not significant at the $5 \%$ level (although it remains significant at the $5 \%$ level for the sample of developing countries). There is, however, a question about whether we want to include the initial level of $T F P$ when testing for the effect of the initial number of Products. On the one hand, including the TFP level allows us to control for spurious correlation induced by omitted third variables 
that separately affect both Products $_{0, i t}$ and $K G r_{i t}$. On the other hand, the theory predicts that a higher initial number of Products, compared to the initial $K$ stock, will imply that the country is farther behind its steady state, and this will be reflected in a higher TFP ( $\omega_{K}$ in the model). ${ }^{22}$ Thus, we really have no compelling reason for believing that in specification (17), the initial number of Products will have an effect on the growth rate of capital even after we hold fixed the initial level of $T F P$.

As discussed above, the theory predicts that both the initial number of Products as well as the NewProducts increment over the 5-year period should have an effect on the growth rate of capital. The results in columns 8 and 9 (of table 3 ) show that when both variables are included in the specification, the estimated coefficient on NewProducts is statistically significant, but that on the initial number of Products is not. In fact,

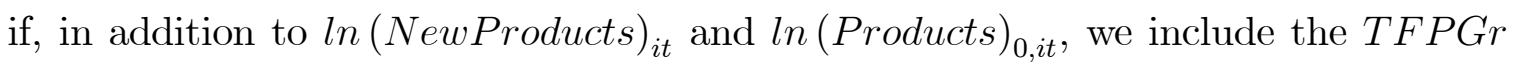
rate in the specification (not shown), the estimated coefficient on $\ln$ (NewProducts) ${ }_{i t}$ is significant only at the $10 \%$ level. The problem here is that the two variables, Product $_{0, i t}$ and NewProducts $s_{i t}$ are highly collinear-the simple bivariate correlation between the two variables is 0.77 . It therefore becomes difficult to obtain precise estimates of the individual effects of these two variables within the same specification. Still, in all such specifications, the coefficients on the two variables are jointly highly significant.

\footnotetext{
${ }^{22}$ Note the distinction here from the issue discussed in the previous section about whether a larger NewProducts is fully reflected in a higher TFPGr rate over a 5-year period. Starting from steady-state, a larger NewProducts over the 5 -year period can stimulate a quick response from the capital stock, such that the level of $T F P$ at the end of the period is unchanged from the beginning, and there is no effect on the measured TFPGr rate over the 5-year period. Thus, including both NewProducts and TFPGr in specification (16) allowed us to legitimately test for the effect of NewProducts on $K G r$ while holding fixed the TFPGr rate. In contrast, the theory predicts that in specification (17), a higher initial number of products, relative to the initial capital stock, must necessarily be reflected in a higher initial level of $T F P$. Thus, we have no legitimate reason to test for the effect of Products $s_{0, i t}$ on $K G r_{i t}$, while holding fixed the initial level of $T F P$.
} 


\subsection{Causality Tests of Effect of NewProducts on Capital Growth}

A counter-argument to our causal interpretation of the estimated positive coefficient on $\ln$ (Products) $_{0, i t}$ can be made on the grounds that $K G r_{i t}$ is correlated with $K G r_{i, t-1}$. Then, since $K G r_{i t-1}$ can lead to a higher NewProducts $s_{i, t-1}$ (the reverse causality problem), and hence lead to a higher Product $s_{0, i t}$, our findings in section 4.2 may still not conclusively demonstrate causality. We thus turn next to looking at the effect of the lagged NewProducts increment on the rate of capital growth. In doing so, we will also hold fixed the lagged growth rate of capital.

The theoretical justification for looking at the effect of NewProducts $s_{i, t-1}$ on $K G r_{i t}$ is clear: given a technological improvement in the form of NewProducts $s_{i, t-1}$, the $K$ stock will likely not respond fully in period $t-1$. Some of the adjustment to the new steady state will carry over into period $t$, so that $K G r_{i t}$ will also be positively impacted. On the other hand, since NewProducts $s_{i, t-1}$ precedes $K G r_{i t}$, the reverse causality argument is not immediately apparent. However, as explained above, $K G r_{i t}$ could be correlated with $K G r_{i, t-1}$ through unobserved third variables, and there exists the reverse causality concern that $K G r_{i, t-1}$ can be responsible for some part of NewProducts $s_{i, t-1}$. Therefore, we also control for $K G r_{i, t-1}$. The specification takes the following form:

$$
\begin{aligned}
K G r_{i t}= & \beta_{0}+\beta_{1} K G r_{i, t-1}+\beta_{2} \ln (K / L)_{0, i t}+\beta_{3} \ln (\text { NewProducts })_{i, t-1} \\
& +\beta_{4} \ln (T F P)_{0, i, t-1}+\beta_{5} \ln (T F P G r)_{i, t-1}+\zeta_{t}+\nu_{i t}
\end{aligned}
$$

The results from estimating several variants of this specification are presented in Tables 4 and 5. The estimates in table 4 do not hold fixed the lagged growth rate of capital. The estimates in this table show that the lagged NewProduct $s_{t-1}$ increment is associated with a higher growth rate of capital in period $t$. The more compelling findings are in table 5, where we hold fixed the growth rate of capital in period $t-1$. This allows us to hold fixed unobserved factors responsible for differences in the lagged growth rate of capital, through which $K G r_{i, t-1}$ affects NewProducts $s_{i, t-1}$. Thus, we are able to take care of the reverse causality concern that NewProducts $s_{i, t-1}$ 
could have resulted from $K G r_{i, t-1}$, which is correlated with $K G r_{i t}{ }^{23}$ The estimated coefficient on NewProduct $s_{i, t-1}$ is positive and statistically significant at the $5 \%$ level, thus providing compelling evidence that a technological improvement, in the form of acquiring the capacity to produce and export new products, leads to a higher rate of capital accumulation. Furthermore, the estimates in columns 3 and 4 show that even after we hold fixed the initial level of TFP and the TFPGr rate in period $t-1$, the effect of NewProducts $s_{i, t-1}$ on the growth rate of capital is positive and statistically significant. This provides compelling evidence that the contribution of a technological improvement-in the form of new product technology-is not fully reflected in a higher rate of $T F P$ growth.

It is worthwhile to point out that the estimated coefficient on $\ln (\text { NewProducts })_{i, t-1}$ in table 5 is likely biased toward zero. Since NewProduct $s_{i, t-1}$ is expected to have an effect on $K G r_{i, t-1}$, by holding fixed $K G r_{i, t-1}$ we are not only holding fixed exogenous factors responsible for a higher growth rate of capital, but also holding fixed the stimulus on $K G r_{i, t-1}$ from NewProduct $s_{i, t-1}$. Thus, the estimates are biased against finding an effect of new product technology on the rate of capital accumulation. In light of this fact, the finding of a positive and significant effect is all the more compelling.

Finally, as a robustness check, the estimates in table 6 test for the effect of our NewTech variable on the rate of capital accumulation. Recall that this variable was constructed as an alternative measure of technological improvements by filtering out factors such as population and distance which may have led some countries to export a larger increment of products to the United States. The results show that NewTech has a statistically significant positive effect on the rate of capital accumulation even after holding fixed the rate of TFP growth, both in the full sample of countries and

\footnotetext{
${ }^{23}$ Note that in the specifications in table 5 , it is not necessary to hold fixed the age dependency ratios because by holding fixed $K G r_{i, t-1}$, we are already holding fixed exogenous reasons why rates of capital growth differ across countries. Thus, we are doing better than only holding fixed Old and Young age ratios.
} 
in the sample of non-OECD developing countries.

\section{Concluding Comments}

We have used a range of specifications to control for problems of reverse causation and omitted third variable-induced spurious correlation in testing for the effect of our measure of technological improvements on the rate of capital accumulation. While the magnitude of the coefficient falls upon controlling for these problems, the effect remains positive and statistically significant. Furthermore, the effect of new product technology on capital accumulation remains significant even after holding fixed the rate of TFP growth. Thus, technological improvements in the form of acquiring the expertise to produce and export new products leads to a higher rate of capital accumulation, without being fully reflected in a higher measured rate of $T F P$ growth.

Both international economists and macroeconomists have struggled to understand the relative contributions of available resources and technological capacity on the structure and size of production. On the one hand, the empirical Heckscher-Ohlin-Vanek literature has used two pieces of information-available factors of production and assumptions about sectoral factor intensities across countries-to predict the structure of production. On the other hand, the growth accounting exercise implements a simple decomposition of economic growth into the contributions of capital accumulation and TFP growth. This paper shows that available resources can respond endogenously to an expansion in technological capacity. We make explicit the nature of such technological improvements-the acquired capacity to produce and export new products-and we also show that such improvements are not fully reflected in a higher growth rate of total factor productivity. True, high rates of economic growth are associated with high growth rates of capital and unspectacular rates of TFP growth. However, these observations may be because stellar technological improvements stimulate high growth rates of capital and are not reflected in stellar measured rates of TFP growth. Thus, while we have no disagreements with the simple decomposition of the growth accounting exercise, our work shows that such simple decompositions 
lack power to make causal interpretations.

This paper opens up an interesting area for further research. While we have shown that an expansion in the range of products within a country's technological capacity provides incentives for more rapid accumulation of capital, there exists a promising research agenda in exploring why some countries have been more successful in acquiring the capacity to produce and export a wider range of products over time. Such an exercise is also likely to yield a richer set of policy guidelines about what countries can do to expand the range of products over which they have technological expertise. 


\section{References}

[1] Acemoglu, Daron and Jaume Ventura, "The World Income Distribution," Quarterly Journal of Economics, May 2002.

[2] Barro, Robert J and Jong-Wha Lee, "International Comparisons of Educational Attainment," Journal of Monetary Economics, December 1993.

[3] Bosworth, Barro and Susan Collins, "Economic Growth in East Asia: Accumulation Versus Assimilation," Brookings Papers on Economic Activity, 1996.

[4] Carroll, Christopher and David Weil, "Saving and Growth: A Reinterpretation," Carnegie-Rochester Conference Series on Public Policy, 1994.

[5] Diewert, W. Erwin and Catherine Morrison, "Adjusting Output and Productivity Indexes for Changes in the Terms of Trade," Economic Journal, September 1986.

[6] Dornbush, Rudiger, Stanley Fischer, and Paul Samuelson, "Comparative Advantage, Trade and Payments in a Ricardian Model with a Continuum of Goods," American Economic Review, December 1977.

[7] Feenstra, Robert, "U.S. Imports, 1972-1994: Data and Concordances," NBER Working Paper \# 5515, March 1996.

[8] Feenstra, Robert and Andrew Rose, "Putting Things in Order: Trade Dynamics and Product Cycles," Review of Economics and Statistics, August 2000.

[9] Foster, Andrew and Mark Rosenzweig, "Technical Change and Human Capital Returns and Investments: Evidence from the Green Revolution," American Economic Review, September 1996.

[10] Grossman, Gene and Elhanan Helpman. Innovation and Growth in the Global Economy. Cambridge: MIT Press, 1991. 
[11] Hausmann, Ricardo and Dani Rodrik, "Economic Development as SelfDiscovery," NBER Working Paper \# 8952, May 2002.

[12] Hsieh, Chang-Tai, "Productivity Growth and Factor Prices in East Asia," American Economic Review Papers and Proceedings, May 1999.

[13] Kohli, Ulrich, "GDP Growth Accounting: A National Income Approach," Review of Income and Wealth, March 2003.

[14] Loayza, Norman, Klaus Schmidt-Hebbel, and Luis Serven, "What Drives Private Saving Across the World?" Review of Economics and Statistics, May 2000.

[15] Nehru, Vikram and Ashok Dhareshwar, "New Estimates of Total Factor Productivity Growth for Developing and Industrial Countries," Policy Research Working Paper \# 1313, The World Bank, 1994.

[16] Rodrik, Dani, "TFPG Controversies, Institutions, and Economic Performance in East Asia," NBER Working Paper \# 5914, February 1997.

[17] Romer, Paul, "Endogenous Technological Change," Journal of Political Economy, October 1990.

[18] Schmidt-Hebbel, Klaus and Luis Serven, "Does Income Inequality Raise Aggregate Saving?" The World Bank, manuscript, 1996.

[19] Stiglitz, Joseph, "Factor Price Equalization in a Dynamic Economy," Journal of Political Economy, May-June 1970.

[20] World Bank, World Development Indicators, 2000.

[21] Ventura, Jaume, "Growth and Interdependence," Quarterly Journal of Economics, February 1997.

[22] Young, Alwyn, "The Tyranny of Numbers: Confronting the Statistical Realities of the East Asian Growth Experience," Quarterly Journal of Economics, August 1995. 
[23] Young, Alwyn, "Paasche vs. Laspeyres: The Elasticity of Substitution and Bias in Measures of TFP Growth," NBER Working Paper \# 6663, July 1998. 
Table A1. Snapshot of the Raw Data:

3 Products Exported by Thailand, starting from the first year of exports

\begin{tabular}{llcrr}
\hline \hline PRODUCT DESCRIPTION & COUNTRY & SITCCODE & YEAR & EXPORTS \\
& & & & \\
BASIC METAL SAFES & THAILAND & 69912 & 87 & 50812 \\
BASIC METAL SAFES & THAILAND & 69912 & 88 & 129276 \\
BASIC METAL SAFES & THAILAND & 69912 & 89 & 1700958 \\
BASIC METAL SAFES & THAILAND & 69912 & 90 & 1639915 \\
BASIC METAL SAFES & THAILAND & 69912 & 91 & 1884810 \\
BASIC METAL SAFES & THAILAND & 69912 & 92 & 2783445 \\
BASIC METAL SAFES & THAILAND & 69912 & 93 & 2422866 \\
BASIC METAL SAFES & THAILAND & 69912 & 94 & 2317455 \\
& & & & \\
NON-ELECTRIC POWER HAND TOOLS & THAILAND & 74511 & 85 & 52889 \\
NON-ELECTRIC POWER HAND TOOLS & THAILAND & 74511 & 86 & 55964 \\
NON-ELECTRIC POWER HAND TOOLS & THAILAND & 74511 & 88 & 81588 \\
NON-ELECTRIC POWER HAND TOOLS & THAILAND & 74511 & 89 & 1353654 \\
NON-ELECTRIC POWER HAND TOOLS & THAILAND & 74511 & 91 & 604647 \\
NON-ELECTRIC POWER HAND TOOLS & THAILAND & 74511 & 92 & 1091445 \\
NON-ELECTRIC POWER HAND TOOLS & THAILAND & 74511 & 93 & 658398 \\
NON-ELECTRIC POWER HAND TOOLS & THAILAND & 74511 & 94 & 829940 \\
& & & & \\
INNER TUBES OF TYRES & THAILAND & 62591 & 87 & 226941 \\
INNER TUBES OF TYRES & THAILAND & 62591 & 88 & 626101 \\
INNER TUBES OF TYRES & THAILAND & 62591 & 89 & 1230986 \\
INNER TUBES OF TYRES & THAILAND & 62591 & 90 & 2024720 \\
INNER TUBES OF TYRES & THAILAND & 62591 & 91 & 2500996 \\
INNER TUBES OF TYRES & THAILAND & 62591 & 92 & 2367285 \\
INNER TUBES OF TYRES & THAILAND & 62591 & 93 & 2626161 \\
INNER TUBES OF TYRES & THAILAND & 62591 & 94 & 1912430 \\
\hline \hline & & & & \\
\hline
\end{tabular}


Table A2. NewProducts and NewTech for select countries, 1972-94

\begin{tabular}{|c|c|c|c|c|c|c|}
\hline $\begin{array}{c}\text { New Products } \\
\text { Rank }\end{array}$ & בCOUNTRY & $\begin{array}{c}\text { Products } \\
1972 \\
\end{array}$ & $\begin{array}{c}\text { New Products } \\
1972-94 \\
\end{array}$ & $\begin{array}{c}\text { NEWTECH } \\
\text { Rank } \\
\end{array}$ & $\overline{\text { COUNTRY }}$ & NEWTECH \\
\hline 1 & China & 96 & 763 & 1 & Singapore & 1.98 \\
\hline 2 & Brazil & 217 & 609 & 2 & Israel & 1.668 \\
\hline 3 & South Korea & 180 & 589 & 3 & New Zealand & 1.612 \\
\hline 4 & Mexico & 370 & 573 & 4 & Australia & 1.552 \\
\hline 5 & Belgium-Lux & 331 & 545 & 5 & Taiwan & 1.472 \\
\hline 6 & Taiwan & 285 & 545 & 6 & Malaysia & 1.358 \\
\hline 7 & Australia & 191 & 538 & 7 & Ireland & 1.253 \\
\hline 8 & Israel & 151 & 519 & 8 & South Korea & 1.238 \\
\hline 9 & India & 176 & 500 & 9 & Belgium-Lux & 1.171 \\
\hline 10 & Spain & 305 & 493 & 10 & South Africa & 1.149 \\
\hline 83 & Malawi & 4 & 19 & 83 & Sudan & -1.938 \\
\hline 84 & Algeria & 7 & 18 & 84 & Algeria & -2.162 \\
\hline 85 & Ethiopia & 14 & 17 & 85 & Uganda & -2.331 \\
\hline 86 & Uganda & 5 & 13 & 86 & Ethiopia & -2.332 \\
\hline 87 & Rwanda & 6 & 6 & 87 & Rwanda & -2.841 \\
\hline
\end{tabular}

$\overline{\text { Note: This table only lists the cumulative number of new products }}$ over the entire 1973-94 period.

Our constructed measure of new products is of course annual and is aggregated into annual 5-year averages for the empirical estimations. 
Table A3. Sample of Developing and OECD Countries

Developing Countries

\begin{tabular}{llllll}
\hline \hline DZA & Algeria & IND & India & PRY & Paraguay \\
ARG & Argentina & IDN & Indonesia & PER & Peru \\
BGD & Bangladesh & IRN & Iran & PHL & Philippines \\
BOL & Bolivia & ISR & Israel & RWA & Rwanda \\
BRA & Brazil & JAM & Jamaica & SEN & Senegal \\
CMR & Cameroon & JOR & Jordan & SLE & Sierra Leone \\
CHL & Chile & KEN & Kenya & SGP & Singapore \\
CHN & China & KOR & Korea & ZAF & South Africa \\
COL & Colombia & MDG & Madagascar & LKA & Sri Lanka \\
CRI & Costa Rica & MWI & Malawi & SDN & Sudan \\
CIV & Cote d'Ivoire & MYS & Malaysia & TWN & Taiwan \\
CYP & Cyprus & MLI & Mali & TZA & Tanzania \\
DOM & Dominican Rep. & MLT & Malta & THA & Thailand \\
ECU & Ecuador & MUS & Mauritius & TTO & Trinidad and Tobago \\
EGY & Egypt & MEX & Mexico & TUN & Tunisia \\
SLV & El Salvador & MAR & Morocco & TUR & Turkey \\
ETH & Ethiopia & MOZ & Mozambique & UGA & Uganda \\
GHA & Ghana & MMR & Myanmar & URY & Uruguay \\
GTM & Guatemala & NIC & Nicaragua & VEN & Venezuela \\
GUY & Guyana & NGA & Nigeria & ZAR & Zaire/D. R .Congo \\
HTI & Haiti & PAK & Pakistan & ZMB & Zambia \\
HND & Honduras & PAN & Panama & ZWE & Zimbabwe \\
\hline \hline
\end{tabular}

OECD Countries

\begin{tabular}{llll}
\hline \hline AUS & Australia & ITA & Italy \\
AUT & Austria & JPN & Japan \\
BEL & Belgium & NLD & Netherlands \\
CAN & Canada & NZL & New Zealand \\
DNK & Denmark & NOR & Norway \\
FIN & Finland & PRT & Portugal \\
FRA & France & ESP & Spain \\
DEU & Germany & SWE & Sweden \\
GRC & Greece & CHE & Switzerland \\
ISL & Iceland & GBR & United Kingdom \\
IRL & Ireland & & \\
\hline \hline
\end{tabular}




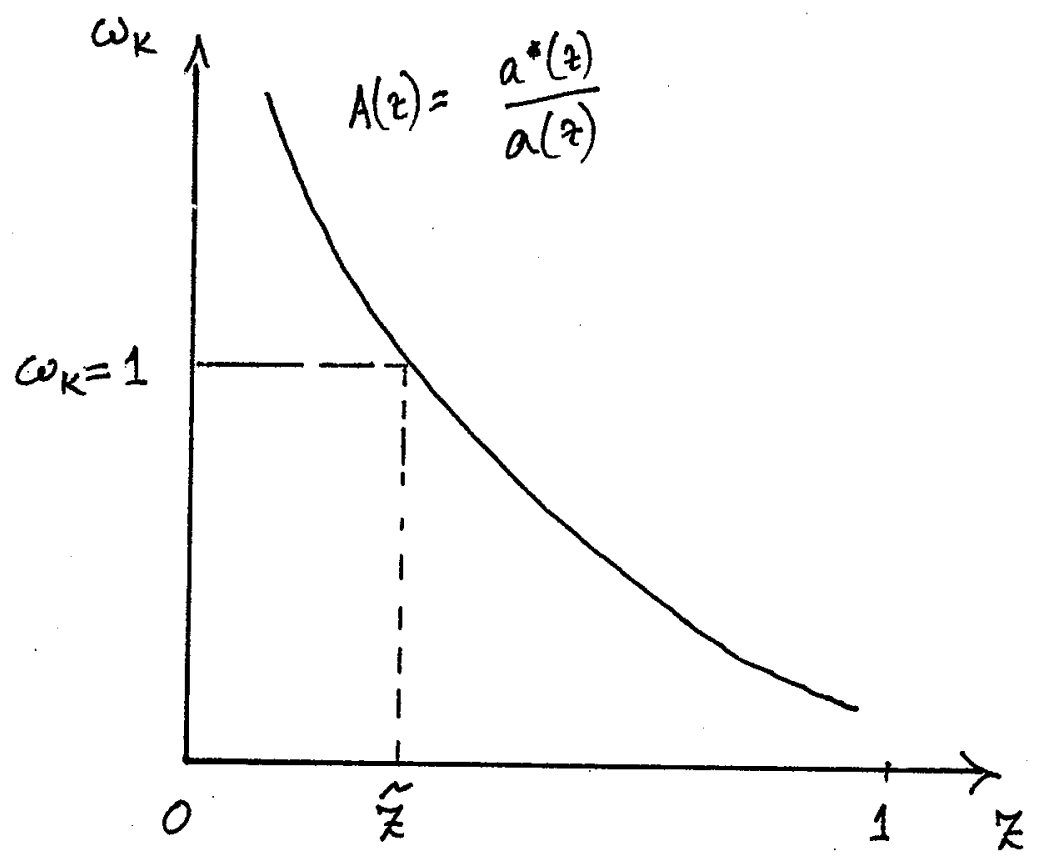

Figure 1. Steady -State Equilibrium

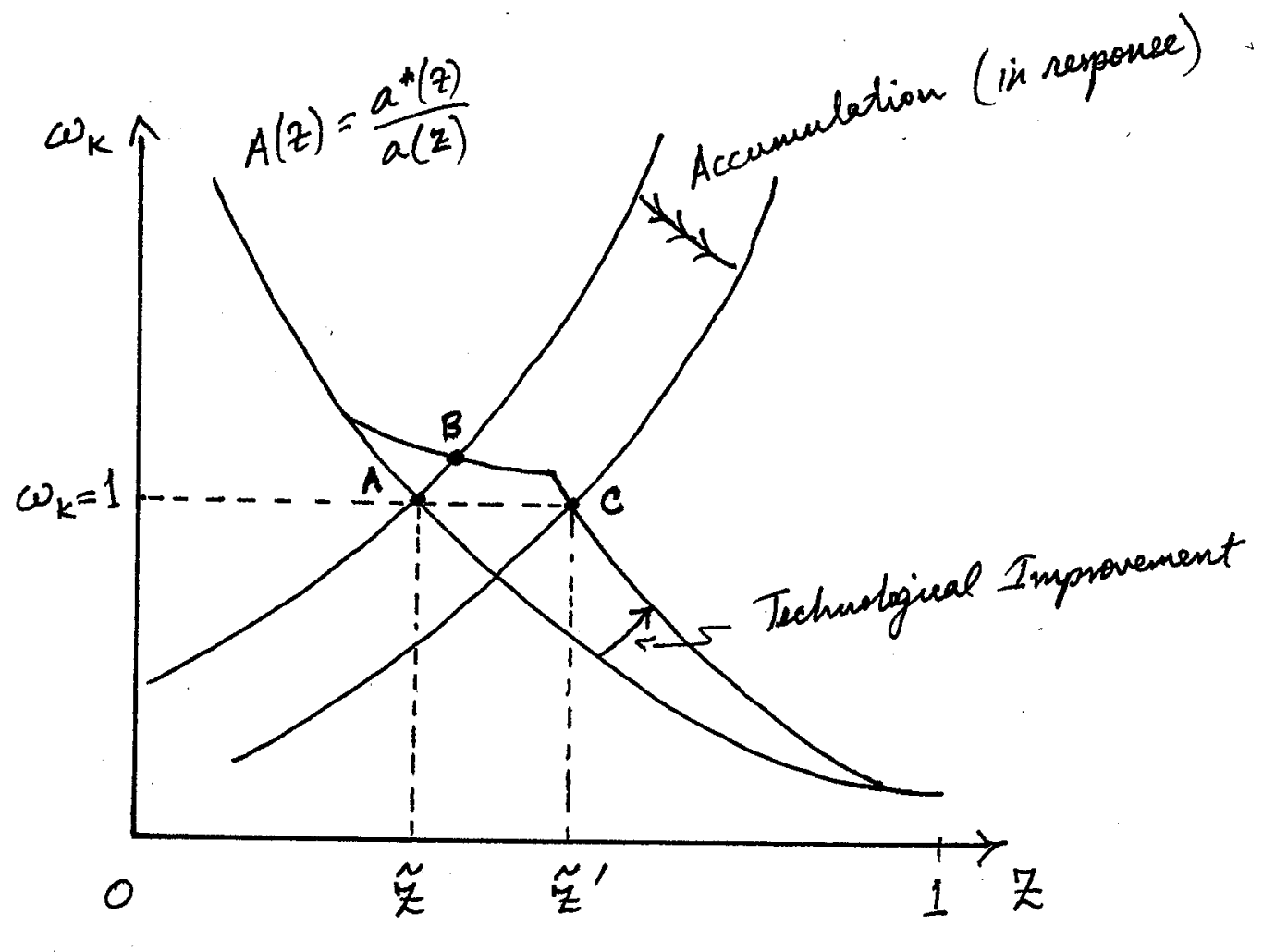

Figure 2. The Effect of a Technological Improvement

36 
Table 2. Panel Estimates of Capital Growth Equations

Effect of NewProducts

Dependent variable is $\mathrm{KGr}_{t}$ (Standard Errors in parentheses)

\begin{tabular}{|c|c|c|c|c|c|c|c|}
\hline & $\overline{11}$ & 2 & $\overline{3}$ & 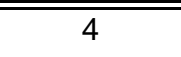 & 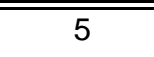 & 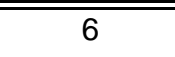 & 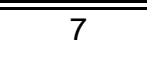 \\
\hline Sample & Full & Full & Full & $\begin{array}{l}\text { Developing } \\
\text { Countries }\end{array}$ & Full & $\begin{array}{c}\text { Developing } \\
\text { Countries }\end{array}$ & OECD \\
\hline Constant & $\begin{array}{l}0.1173^{* *} \\
(0.0120)\end{array}$ & $\begin{array}{l}0.2342^{* *} \\
(0.0310)\end{array}$ & $\begin{array}{l}0.2586^{* *} \\
(0.0306)\end{array}$ & $\begin{array}{l}0.2625^{\star *} \\
(0.0331)\end{array}$ & $\begin{array}{l}0.2324^{* *} \\
(0.0310)\end{array}$ & $\begin{array}{l}0.2334^{* *} \\
(0.0341)\end{array}$ & $\begin{array}{l}0.4277^{* *} \\
(0.0789)\end{array}$ \\
\hline $\ln (\mathrm{K} / \mathrm{L})_{0, \mathrm{t}}$ & $\begin{array}{l}-0.0073^{\star *} \\
(0.0013)\end{array}$ & $\begin{array}{c}-0.0052^{\star *} \\
(0.0020)\end{array}$ & $\begin{array}{c}-0.0170^{* *} \\
(0.0024)\end{array}$ & $\begin{array}{l}-0.0168^{\star *} \\
(0.0025)\end{array}$ & $\begin{array}{c}-0.0172^{* *} \\
(0.0024)\end{array}$ & $\begin{array}{l}-0.0170^{\star \star} \\
(0.0025)\end{array}$ & $\begin{array}{c}-0.0254^{* *} \\
(0.0064)\end{array}$ \\
\hline $\ln (\text { NewProducts })_{\mathrm{t}}$ & $\begin{array}{l}0.0084^{\star *} \\
(0.0016)\end{array}$ & $\begin{array}{l}0.0057^{\star *} \\
(0.0015)\end{array}$ & $\begin{array}{l}0.0040^{* *} \\
(0.0014)\end{array}$ & $\begin{array}{l}0.0048^{* *} \\
(0.0016)\end{array}$ & $\begin{array}{l}0.0033^{\star *} \\
(0.0013)\end{array}$ & $\begin{array}{l}0.0041^{* *} \\
(0.0015)\end{array}$ & $\begin{array}{c}-0.0045^{\star *} \\
(0.0014)\end{array}$ \\
\hline $\ln (\mathrm{TFP})_{0, \mathrm{t}}$ & & & $\begin{array}{l}0.0392^{* *} \\
(0.0046)\end{array}$ & $\begin{array}{l}0.0392^{* *} \\
(0.0049)\end{array}$ & $\begin{array}{l}0.0437^{\star *} \\
(0.0047)\end{array}$ & $\begin{array}{l}0.0440 \text { ** } \\
(0.0050)\end{array}$ & $\begin{array}{l}-0.0024 \\
(0.0074)\end{array}$ \\
\hline TFPGR $_{t}$ & & & & & $\begin{array}{l}0.2473^{\star \star} \\
(0.0526)\end{array}$ & $\begin{array}{l}0.2538^{\star *} \\
(0.0564)\end{array}$ & $\begin{array}{c}0.0037 \\
(0.0888)\end{array}$ \\
\hline Old_Dep_Ratio & & $\begin{array}{c}-0.0063^{\star *} \\
(0.0008)\end{array}$ & $\begin{array}{l}-0.0062^{\star *} \\
(0.0007)\end{array}$ & $\begin{array}{c}-0.0060^{\star *} \\
(0.0013)\end{array}$ & $\begin{array}{c}-0.0058^{\star *} \\
(0.0007)\end{array}$ & $\begin{array}{c}-0.0058^{\star *} \\
(0.0013)\end{array}$ & $\begin{array}{c}-0.0030^{* *} \\
(0.0008)\end{array}$ \\
\hline Young_Dep_Ratio & & $\begin{array}{c}-0.0025^{\star *} \\
(0.0004)\end{array}$ & $\begin{array}{c}-0.0022^{\star *} \\
(0.0004)\end{array}$ & $\begin{array}{c}-0.0024^{\star *} \\
(0.0005)\end{array}$ & $\begin{array}{c}-0.0017^{\star *} \\
(0.0004)\end{array}$ & $\begin{array}{c}-0.0018^{* *} \\
(0.0005)\end{array}$ & $\begin{array}{c}-0.0015^{\star *} \\
(0.0006)\end{array}$ \\
\hline Time Fixed Effects & Yes & Yes & Yes & Yes & Yes & Yes & Yes \\
\hline $\begin{array}{l}R^{2} \\
\text { Number of Obs. }\end{array}$ & $\begin{array}{c}0.245 \\
429\end{array}$ & $\begin{array}{c}0.332 \\
429\end{array}$ & $\begin{array}{c}0.449 \\
429\end{array}$ & $\begin{array}{c}0.447 \\
324\end{array}$ & $\begin{array}{c}0.484 \\
429\end{array}$ & $\begin{array}{c}0.484 \\
324\end{array}$ & $\begin{array}{c}0.728 \\
105\end{array}$ \\
\hline
\end{tabular}

Equations estimated using heteroskedasticity-consistent standard errors.

** $\&$ * denote coeff is significantly different from zero at $5 \%$ \& $10 \%$ level respectively 
Table 3. Panel Estimates of Capital Growth Equations:

Effect of Initial \# Products

Dependent variable is $K G r_{t}$ (Standard Errors in parentheses)

\begin{tabular}{|c|c|c|c|c|c|c|c|c|c|}
\hline & 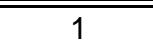 & $\overline{2}$ & $\overline{3}$ & $\overline{44}$ & 5 & $\overline{6}$ & $\overline{77}$ & $\overline{88}$ & $\overline{99}$ \\
\hline Sample & Full & Full & $\begin{array}{c}\text { Developing } \\
\text { Countries }\end{array}$ & Full & $\begin{array}{c}\text { Developing } \\
\text { Countries }\end{array}$ & Full & $\begin{array}{c}\text { Developing } \\
\text { Countries }\end{array}$ & Full & $\begin{array}{c}\text { Developing } \\
\text { Countries }\end{array}$ \\
\hline Constant & $\begin{array}{l}0.1064^{\star \star} \\
(0.0125)\end{array}$ & $\begin{array}{l}0.2274^{\star *} \\
(0.0298)\end{array}$ & $\begin{array}{l}0.2381^{* *} \\
(0.0325)\end{array}$ & $\begin{array}{l}0.2307^{\star *} \\
(0.0293)\end{array}$ & $\begin{array}{l}0.2300^{* *} \\
(0.0319)\end{array}$ & $\begin{array}{l}0.2084^{\star \star} \\
(0.0308)\end{array}$ & $\begin{array}{l}0.2182^{\star *} \\
(0.0338)\end{array}$ & $\begin{array}{l}0.2307^{\star *} \\
(0.0300)\end{array}$ & $\begin{array}{l}0.2423^{\star *} \\
(0.0328)\end{array}$ \\
\hline $\ln (\mathrm{K} / \mathrm{L})_{0, \mathrm{t}}$ & $\begin{array}{c}-0.0067^{\star *} \\
(0.0016)\end{array}$ & $\begin{array}{l}-0.0044^{* *} \\
(0.0020)\end{array}$ & $\begin{array}{l}-0.0041^{*} \\
(0.0022)\end{array}$ & $\begin{array}{c}-0.0166^{* *} \\
(0.0023)\end{array}$ & $\begin{array}{c}-0.0165^{\star *} \\
(0.0025)\end{array}$ & $\begin{array}{c}-0.0039^{* *} \\
(0.0019)\end{array}$ & $\begin{array}{l}-0.0036^{*} \\
(0.0022)\end{array}$ & $\begin{array}{l}-0.0052^{* *} \\
(0.0020)\end{array}$ & $\begin{array}{c}-0.0050^{\star *} \\
(0.0021)\end{array}$ \\
\hline In(Initial \# Products $)_{0, t}$ & $\begin{array}{l}0.0056^{\star *} \\
(0.0015)\end{array}$ & $\begin{array}{l}0.0044^{\star *} \\
(0.0015)\end{array}$ & $\begin{array}{l}0.0055^{\star *} \\
(0.0018)\end{array}$ & $\begin{array}{c}0.0019 \\
(0.0012)\end{array}$ & $\begin{array}{l}0.0029^{* *} \\
(0.0014)\end{array}$ & $\begin{array}{l}0.0046^{\star *} \\
(0.0014)\end{array}$ & $\begin{array}{l}0.0057^{\star *} \\
(0.0017)\end{array}$ & $\begin{array}{c}0.0011 \\
(0.0021)\end{array}$ & $\begin{array}{c}0.0010 \\
(0.0029)\end{array}$ \\
\hline $\ln (\text { NewProducts })_{\mathrm{t}}$ & & & & & & & & $\begin{array}{l}0.0049^{\star *} \\
(0.0021)\end{array}$ & $\begin{array}{l}0.0061^{\star *} \\
(0.0028)\end{array}$ \\
\hline $\ln (\mathrm{TFP})_{0, \mathrm{t}}$ & & & & $\begin{array}{l}0.0444^{\star *} \\
(0.0046)\end{array}$ & $\begin{array}{l}0.0450^{\star *} \\
(0.0048)\end{array}$ & & & & \\
\hline TFPGR $_{\mathrm{t}}$ & & & & $\begin{array}{l}0.2559^{* *} \\
(0.0496)\end{array}$ & $\begin{array}{l}0.2628^{\star *} \\
(0.0534)\end{array}$ & $\begin{array}{l}0.1550^{\star *} \\
(0.0631)\end{array}$ & $\begin{array}{l}0.1547^{* *} \\
(0.0673)\end{array}$ & & \\
\hline Old_Dep_Ratio & & $\begin{array}{c}-0.0069^{\star *} \\
(0.0008)\end{array}$ & $\begin{array}{c}-0.0075^{\star *} \\
(0.0015)\end{array}$ & $\begin{array}{l}-0.0062^{* *} \\
(0.0007)\end{array}$ & $\begin{array}{l}-0.0062^{* *} \\
(0.0013)\end{array}$ & $\begin{array}{c}-0.0065^{\star *} \\
(0.0008)\end{array}$ & $\begin{array}{l}-0.0073^{\star *} \\
(0.0015)\end{array}$ & $\begin{array}{l}-0.0063^{* *} \\
(0.0008)\end{array}$ & $\begin{array}{c}-0.0070^{* *} \\
(0.0015)\end{array}$ \\
\hline Young_Dep_Ratio & & $\begin{array}{c}-0.0026^{\star *} \\
(0.0004)\end{array}$ & $\begin{array}{c}-0.0029^{* *} \\
(0.0005)\end{array}$ & $\begin{array}{c}-0.0018^{* *} \\
(0.0004)\end{array}$ & $\begin{array}{c}-0.0019 * * \\
(0.0005)\end{array}$ & $\begin{array}{c}-0.0023^{* *} \\
(0.0004)\end{array}$ & $\begin{array}{c}-0.0026^{* *} \\
(0.0005)\end{array}$ & $\begin{array}{c}-0.0025^{\star *} \\
(0.0004)\end{array}$ & $\begin{array}{c}-0.0027^{\star *} \\
(0.0005)\end{array}$ \\
\hline Time Fixed Effects & Yes & Yes & Yes & Yes & Yes & Yes & Yes & Yes & Yes \\
\hline $\begin{array}{l}\mathrm{R}^{2} \\
\text { Number of Obs. }\end{array}$ & $\begin{array}{c}0.210 \\
435\end{array}$ & $\begin{array}{c}0.320 \\
435\end{array}$ & $\begin{array}{c}0.312 \\
330\end{array}$ & $\begin{array}{c}0.479 \\
435\end{array}$ & $\begin{array}{c}0.479 \\
330\end{array}$ & $\begin{array}{c}0.335 \\
435\end{array}$ & $\begin{array}{c}0.327 \\
330\end{array}$ & $\begin{array}{c}0.332 \\
429\end{array}$ & $\begin{array}{c}0.328 \\
324\end{array}$ \\
\hline
\end{tabular}

Equations estimated using heteroskedasticity-consistent standard errors.

${ }^{* *} \&{ }^{*}$ denote coeff is significantly different from zero at $5 \%$ \& $10 \%$ level respectively 
Table 4. Causality Tests of NewProducts on Capital Growth

Dependent variable is $\mathrm{KGr}_{t}$ (Standard Errors in parentheses)

\begin{tabular}{|c|c|c|c|c|c|c|}
\hline & 1 & 2 & 3 & 4 & 5 & 6 \\
\hline Sample & Full & Full & $\begin{array}{l}\text { Developing } \\
\text { Countries }\end{array}$ & Full & $\begin{array}{l}\text { Developing } \\
\text { Countries }\end{array}$ & $\begin{array}{c}\text { Developing } \\
\text { Countries }\end{array}$ \\
\hline Constant & $\begin{array}{l}0.1017^{\star \star} \\
(0.0142)\end{array}$ & $\begin{array}{l}0.2553^{\star *} \\
(0.0319)\end{array}$ & $\begin{array}{l}0.2617^{\star \star} \\
(0.0344)\end{array}$ & $\begin{array}{l}0.2919^{\star *} \\
(0.0320)\end{array}$ & $\begin{array}{l}0.2955^{\star \star} \\
(0.0336)\end{array}$ & $\begin{array}{l}0.2700^{\star *} \\
(0.0314)\end{array}$ \\
\hline $\ln (K / L)_{0, t}$ & $\begin{array}{l}-0.0085^{\star *} \\
(0.0016)\end{array}$ & $\begin{array}{c}-0.0079^{\star *} \\
(0.0023)\end{array}$ & $\begin{array}{l}-0.0076^{\star *} \\
(0.0024)\end{array}$ & $\begin{array}{c}-0.0164^{\star *} \\
(0.0029)\end{array}$ & $\begin{array}{l}-0.0166^{\star *} \\
(0.0031)\end{array}$ & $\begin{array}{c}-0.0167^{\star *} \\
(0.0028)\end{array}$ \\
\hline $\ln (\text { NewProducts })_{\mathrm{t}-1}$ & $\begin{array}{l}0.0085^{\star *} \\
(0.0017)\end{array}$ & $\begin{array}{l}0.0046^{\star \star} \\
(0.0015)\end{array}$ & $\begin{array}{l}0.0051^{\star *} \\
(0.0017)\end{array}$ & $\begin{array}{l}0.0035^{\star \star} \\
(0.0015)\end{array}$ & $\begin{array}{l}0.0039^{\star *} \\
(0.0016)\end{array}$ & $\begin{array}{l}0.0030^{* *} \\
(0.0015)\end{array}$ \\
\hline $\ln (T F P)_{0, t-1}$ & & & & $\begin{array}{l}0.0262^{\star \star} \\
(0.0048)\end{array}$ & $\begin{array}{l}0.0271^{\star *} \\
(0.0051)\end{array}$ & $\begin{array}{l}0.0343^{* *} \\
(0.0048)\end{array}$ \\
\hline TFPGR $_{t-1}$ & & & & & & $\begin{array}{l}0.3704^{\star *} \\
(0.0607)\end{array}$ \\
\hline Old_Dep_Ratio ${ }_{t}$ & & $\begin{array}{c}-0.0069^{\star *} \\
(0.0008)\end{array}$ & $\begin{array}{l}-0.0071^{\star *} \\
(0.0015)\end{array}$ & $\begin{array}{l}-0.0070^{\star *} \\
(0.0008)\end{array}$ & $\begin{array}{c}-0.0065^{\star *} \\
(0.0014)\end{array}$ & $\begin{array}{c}-0.0068^{\star *} \\
(0.0013)\end{array}$ \\
\hline Young_Dep_Ratio ${ }_{t}$ & & $\begin{array}{l}-0.0031^{\star *} \\
(0.0004)\end{array}$ & $\begin{array}{c}-0.0034^{\star *} \\
(0.0005)\end{array}$ & $\begin{array}{l}-0.0031^{\star *} \\
(0.0004)\end{array}$ & $\begin{array}{l}-0.0033^{\star *} \\
(0.0004)\end{array}$ & $\begin{array}{l}-0.0028^{* *} \\
(0.0004)\end{array}$ \\
\hline Time Fixed Effects & Yes & Yes & Yes & Yes & Yes & Yes \\
\hline $\begin{array}{l}\mathrm{R}^{2} \\
\text { Number of Obs. }\end{array}$ & $\begin{array}{c}0.222 \\
343 \\
\end{array}$ & $\begin{array}{c}0.352 \\
343 \\
\end{array}$ & $\begin{array}{c}0.361 \\
259 \\
\end{array}$ & $\begin{array}{c}0.407 \\
343 \\
\end{array}$ & $\begin{array}{c}0.421 \\
259 \\
\end{array}$ & $\begin{array}{c}0.509 \\
259\end{array}$ \\
\hline
\end{tabular}

Equations estimated using heteroskedasticity-consistent standard errors.

${ }^{* *} \&$ * denote coeff is significantly different from zero at $5 \%$ \& $10 \%$ level respectively 
Table 5. Panel Causality Tests of NewProducts on Capital Growth Dependent variable is $\mathrm{KGr}_{t}$ (Standard Errors in parentheses)

\begin{tabular}{|c|c|c|c|c|c|}
\hline & 1 & 2 & 3 & 4 & 5 \\
\hline Sample & Full & Full & Full & $\begin{array}{c}\text { Developing } \\
\text { Countries }\end{array}$ & OECD \\
\hline Constant & $\begin{array}{l}0.0463^{* *} \\
(0.0108)\end{array}$ & $\begin{array}{l}0.0561^{\star *} \\
(0.0153)\end{array}$ & $\begin{array}{l}0.0743^{\star *} \\
(0.0152)\end{array}$ & $\begin{array}{l}0.0628^{* *} \\
(0.0173)\end{array}$ & $\begin{array}{c}0.0648 \\
(0.0467)\end{array}$ \\
\hline $\ln (\mathrm{K} / \mathrm{L})_{0, \mathrm{t}}$ & $\begin{array}{l}-0.0049 * * \\
(0.0011)\end{array}$ & $\begin{array}{l}-0.0069^{* *} \\
(0.0023)\end{array}$ & $\begin{array}{l}-0.0094^{* *} \\
(0.0022)\end{array}$ & $\begin{array}{l}-0.0087^{* *} \\
(0.0025)\end{array}$ & $\begin{array}{l}-0.0061 \\
(0.0045)\end{array}$ \\
\hline$K G r_{\mathrm{t}-1}$ & $\begin{array}{l}0.6595^{\star *} \\
(0.0384)\end{array}$ & $\begin{array}{l}0.6427^{\star \star} \\
(0.0432)\end{array}$ & $\begin{array}{l}0.5984^{\star *} \\
(0.0408)\end{array}$ & $\begin{array}{l}0.5760^{\star *} \\
(0.0449)\end{array}$ & $\begin{array}{l}0.6040^{* *} \\
(0.0753)\end{array}$ \\
\hline $\ln (\text { NewProducts })_{\mathrm{t}-1}$ & $\begin{array}{l}0.0041^{\star *} \\
(0.0011)\end{array}$ & $\begin{array}{l}0.0039^{* *} \\
(0.0011)\end{array}$ & $\begin{array}{l}0.0031^{* *} \\
(0.0010)\end{array}$ & $\begin{array}{l}0.0035^{\star *} \\
(0.0010)\end{array}$ & $\begin{array}{c}0.0006 \\
(0.0014)\end{array}$ \\
\hline $\ln (T F P)_{0, t-1}$ & & $\begin{array}{c}0.0059 \\
(0.0047)\end{array}$ & $\begin{array}{l}0.0124^{* *} \\
(0.0047)\end{array}$ & $\begin{array}{l}0.0141^{\star *} \\
(0.0052)\end{array}$ & $\begin{array}{c}0.0036 \\
(0.0069)\end{array}$ \\
\hline TFPGR $_{\mathrm{t}-1}$ & & & $\begin{array}{l}0.2709^{\star *} \\
(0.0482)\end{array}$ & $\begin{array}{l}0.2795^{\star *} \\
(0.0511)\end{array}$ & $\begin{array}{c}0.0903 \\
(0.0936)\end{array}$ \\
\hline Time Fixed Effects & Yes & Yes & Yes & Yes & Yes \\
\hline $\begin{array}{l}R^{2} \\
\text { Number of Obs. }\end{array}$ & $\begin{array}{c}0.611 \\
343 \\
\end{array}$ & $\begin{array}{c}0.614 \\
343 \\
\end{array}$ & $\begin{array}{c}0.663 \\
343 \\
\end{array}$ & $\begin{array}{c}0.670 \\
259 \\
\end{array}$ & $\begin{array}{c}0.670 \\
84 \\
\end{array}$ \\
\hline
\end{tabular}


Table 6. Tests for Effect of NewTech on Capital Growth

Dependent variable is $\mathrm{KGr}_{t}$ (Standard Errors in parentheses)

\begin{tabular}{|c|c|c|c|c|c|}
\hline & 1 & 2 & 3 & 4 & 5 \\
\hline Sample & Full & Full & $\begin{array}{l}\text { Developing } \\
\text { Countries }\end{array}$ & Full & $\begin{array}{l}\text { Developing } \\
\text { Countries }\end{array}$ \\
\hline Constant & $\begin{array}{l}0.1372^{* *} \\
(0.0146)\end{array}$ & $\begin{array}{l}0.2400^{* *} \\
(0.0311)\end{array}$ & $\begin{array}{l}0.2410^{* *} \\
(0.0342)\end{array}$ & $\begin{array}{l}0.0850^{\star *} \\
(0.0163)\end{array}$ & $\begin{array}{l}0.0769^{\star *} \\
(0.0183)\end{array}$ \\
\hline $\ln (\mathrm{K} / \mathrm{L})_{0, \mathrm{t}}$ & $\begin{array}{l}-0.0078^{* *} \\
(0.0014)\end{array}$ & $\begin{array}{l}-0.0177^{* *} \\
(0.0024)\end{array}$ & $\begin{array}{l}-0.0174^{\star *} \\
(0.0025)\end{array}$ & $\begin{array}{l}-0.0101^{\text {** }} \\
(0.0023)\end{array}$ & $\begin{array}{l}-0.0095^{* *} \\
(0.0025)\end{array}$ \\
\hline$K G r_{t-1}$ & & & & $\begin{array}{l}0.5962^{* *} \\
(0.0411)\end{array}$ & $\begin{array}{l}0.5741^{* *} \\
(0.0454)\end{array}$ \\
\hline NewTech $_{\mathrm{t}-1}$ & & & & $\begin{array}{l}0.0037^{* *} \\
(0.0011)\end{array}$ & $\begin{array}{l}0.0044^{* *} \\
(0.0013)\end{array}$ \\
\hline $\ln (T F P)_{0, t-1}$ & & & & $\begin{array}{l}0.0131^{\star *} \\
(0.0047)\end{array}$ & $\begin{array}{l}0.0143^{\star \star} \\
(0.0053)\end{array}$ \\
\hline TFPGR $_{\mathrm{t}-1}$ & & & & $\begin{array}{l}0.2658^{* *} \\
(0.0477)\end{array}$ & $\begin{array}{l}0.2688^{* *} \\
(0.0507)\end{array}$ \\
\hline NewTech $_{\mathrm{t}}$ & $\begin{array}{l}0.0091^{* *} \\
(0.0019)\end{array}$ & $\begin{array}{l}0.0038^{* *} \\
(0.0015)\end{array}$ & $\begin{array}{l}0.0050^{* *} \\
(0.0019)\end{array}$ & & \\
\hline $\ln (T F P)_{0, t}$ & & $\begin{array}{l}0.0444^{\star *} \\
(0.0045)\end{array}$ & $\begin{array}{l}0.0443^{\star *} \\
(0.0049)\end{array}$ & & \\
\hline TFPGR $_{\mathrm{t}}$ & & $\begin{array}{l}0.2426^{\star \star} \\
(0.0532)\end{array}$ & $\begin{array}{l}0.2500^{* *} \\
(0.0568)\end{array}$ & & \\
\hline Old_Dep_Ratio ${ }_{t}$ & & $\begin{array}{l}-0.0057^{* *} \\
(0.0007)\end{array}$ & $\begin{array}{l}-0.0059^{* *} \\
(0.0013)\end{array}$ & & \\
\hline Young_Dep_Ratio & & $\begin{array}{l}-0.0017^{\star \star} \\
(0.0004)\end{array}$ & $\begin{array}{c}-0.0017^{\star *} \\
(0.0005)\end{array}$ & & \\
\hline Time Fixed Effects & Yes & Yes & Yes & Yes & Yes \\
\hline $\begin{array}{l}\mathrm{R}^{2} \\
\text { Number of Obs. }\end{array}$ & $\begin{array}{c}0.242 \\
429\end{array}$ & $\begin{array}{c}0.485 \\
429\end{array}$ & $\begin{array}{c}0.485 \\
324\end{array}$ & $\begin{array}{c}0.664 \\
343\end{array}$ & $\begin{array}{c}0.672 \\
259\end{array}$ \\
\hline
\end{tabular}

Equations estimated using heteroskedasticity-consistent standard errors.

${ }^{* *} \&$ * denote coeff is significantly different from zero at $5 \%$ \& $10 \%$ level respectively 


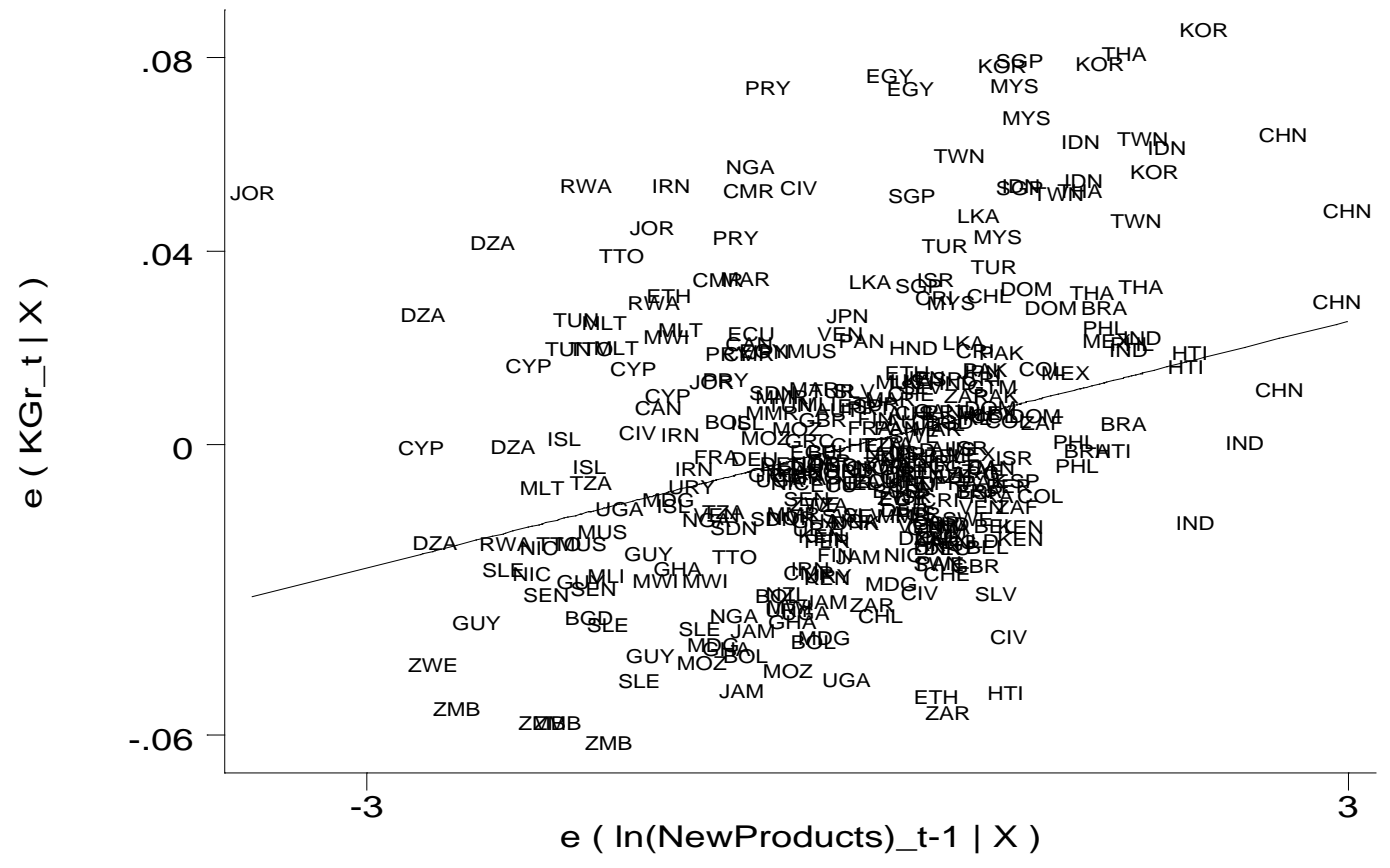

Figure 3. Partial Plot of $K G r_{\mathrm{t}}$ vs. $\ln (\text { NewProducts })_{\mathrm{t}-1}$ :

Controlling for $\ln (K / L)_{0, t}$.

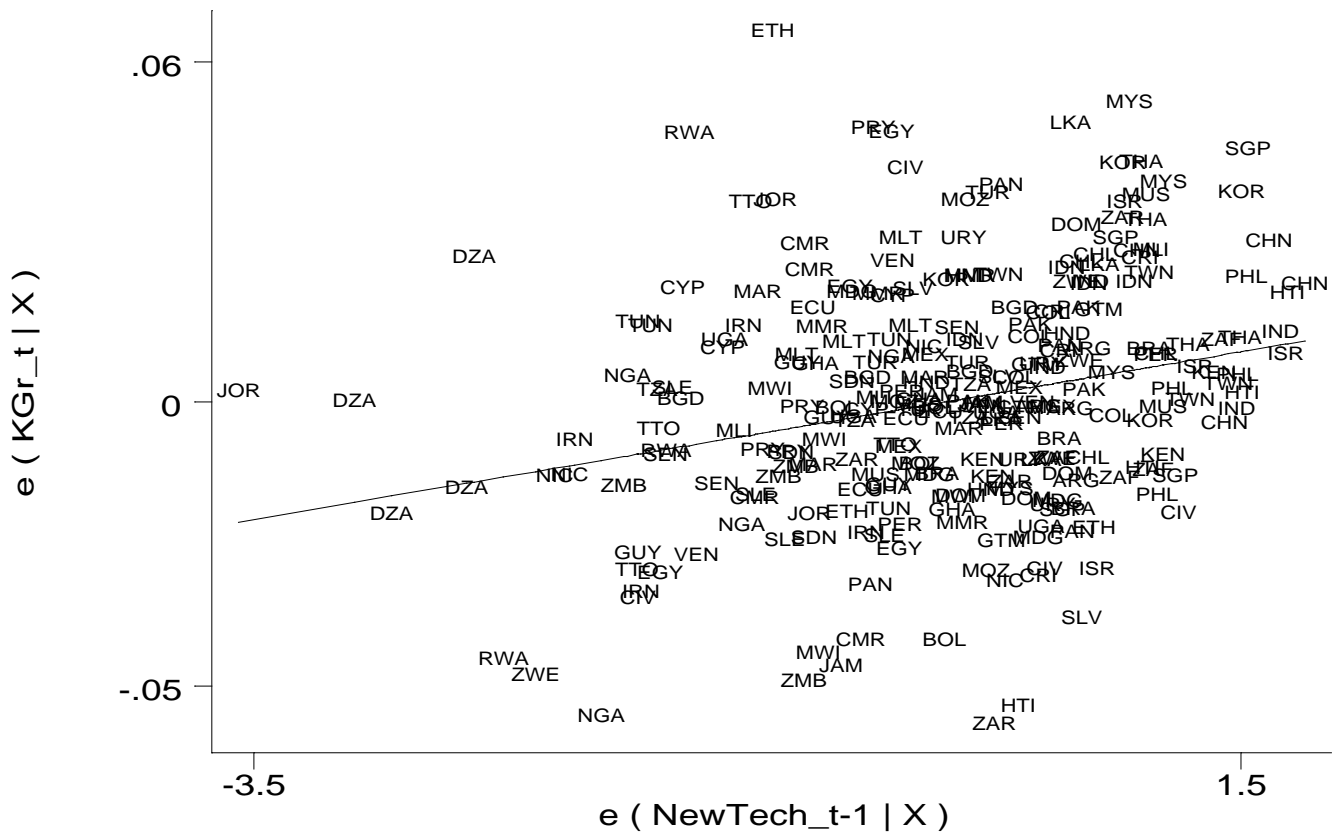

Figure 4. Partial Plot of $K G r_{\mathrm{t}}$ vs. NewTech $\mathrm{t}_{\mathrm{t}-1}$ :

Controlling for $K G r_{\mathrm{t}-1}$ and $\ln (K / L)_{0}$. 